\title{
THE USE OF ASBESTOS WASTES AS A FILLERS ON SOREL CEMENT
}

\author{
"ROBERT KUSIOROWSKI*, TERESA ZAREMBA** \\ *Institute of Ceramics and Building Materials, Refractory Materials Division in Gliwice, \\ ul. Toszecka 99, 44-100 Gliwice, Poland \\ **Silesian University of Technology, Faculty of Chemistry, Department of Inorganic, Analytical Chemistry \\ and Electrochemistry, ul. B. Krzywoustego 6, 44-100 Gliwice, Poland \\ \#E-mail: r.kusiorowski@icimb.pl or robert.kusiorowski@interia.pl
}

Submitted July 3, 2017; accepted September 10, 2017

\begin{abstract}
Keywords: Magnesium oxychloride cement, Asbestos containing materials, Fillers, Recycling, Thermal treatment
The paper presents the results of research on the usefulness of asbestos wastes as Sorel cement fillers. Chrysotile asbestos and cement-asbestos boards were previously pretreated by heat treatment to destroy the fibrous structure of asbestos. The raw materials component used in the study contained from 0 to 40 mass \% of calcined asbestos wastes. The setting time, compressive strength at 3, 7 and 28 days of ripening, phase composition and microstructure of Sorel cements were examined. The results of the preliminary studies indicate that calcined asbestos wastes may be used as Sorel cement fillers. Favourable results were obtained with the use of calcined chrysotile asbestos as compared to cement-asbestos.
\end{abstract}

\section{INTRODUCTION}

Magnesia cement (Sorel cement) is an air binder prepared by in situ reaction of $\mathrm{MgO}$ with a concentrated solution of magnesium chloride, usually in the range of 20 - 30 mass \%. It binds and hardens, thus giving considerable strength in a short period of time. The reactive magnesium oxide used to prepare Sorel cement is usually obtained by calcination of natural magnesite $\left(\mathrm{MgCO}_{3}\right)$ in a carefully selected temperature $\left(700-850^{\circ} \mathrm{C}\right)$ and by fine milling in the next stage. For the production of magnesia cement - as a replacement of caustic magnesite - caustic dolomite obtained by calcining and grinding dolomite rocks $\left(\mathrm{CaCO}_{3} \cdot \mathrm{MgCO}_{3}\right)$ is also used. In addition to commercially exploited magnesia and dolomite rocks, a potential source of $\mathrm{MgO}$ is also basic magnesium carbonate $\left(4 \mathrm{MgCO}_{3} \cdot \mathrm{Mg}(\mathrm{OH})_{2} \cdot 4 \mathrm{H}_{2} \mathrm{O}\right)$, which decomposes at a temperature in the range of $500-600^{\circ} \mathrm{C}$. However, as this reagent's lowest calcination temperature a temperature of $700^{\circ} \mathrm{C}$ is adopted to avoid excessive setting of Sorel cement paste during the mixing of magnesium oxide with magnesium chloride solution [1-3].

The solution of magnesium chloride is most commonly used to prepare magnesia cement. Magnesium sulfate is less often applied. In practice, technical hydrated magnesium chloride $\left(\mathrm{MgCl}_{2} \cdot 6 \mathrm{H}_{2} \mathrm{O}\right)$ is used, which is a byproduct of the potassium salt industry $[1,2]$.

Sorel cement is also called magnesium oxychloride cement (MOC) because initially it was thought that the hardened product contains simple magnesium oxychloride $(\mathrm{Mg}(\mathrm{OH}) \mathrm{Cl})$ formed by the reaction of $\mathrm{MgO}$ with an aqueous solution of $\mathrm{MgCl}_{2}$. In fact, the process of setting and hardening of Sorel cement is much more complicated. A series of reactions take place to form the main phase, such as $\mathrm{Mg}_{3}(\mathrm{OH})_{5} \mathrm{Cl} \cdot 4 \mathrm{H}_{2} \mathrm{O}$ (named as Phase 5), $\mathrm{Mg}_{2}(\mathrm{OH})_{3} \mathrm{Cl} \cdot 4 \mathrm{H}_{2} \mathrm{O}$ (Phase 3), $\mathrm{Mg}_{2}(\mathrm{OH}) \mathrm{ClCO}_{3}$. $\cdot 3 \mathrm{H}_{2} \mathrm{O}$ (Phase A) and $\mathrm{Mg}_{5}(\mathrm{OH})_{2}\left(\mathrm{CO}_{3}\right)_{4} \cdot 4 \mathrm{H}_{2} \mathrm{O}$ (Phase B). During the binding of Sorel cement, Phase 5 crystallises more quickly than Phase 3, while Phase 3 is subjected to faster carbonisation. Due to lower solubility in water, the formation of oxycarbonates has a beneficial effect on the stability of Sorel cement in the long term. Hardened Sorel cement achieves maximum strength when Phase 5 is the main end product [1].

The main application of MOC was in seamless stonewood floors, also known as xylolite, made from mortars based on Sorel cement and fillers in the form of sawdust and/or wood shavings as well as mineral fillers and pigments. The addition of mineral filler such as ground quartz in exchange for a part of the wood filler improves resistance to abrasion. Powdered talc can also be added as it also improves abrasion resistance and reduces water absorption of the material. When the floor hardens, it can be protected from water by polishing it with wax with turpentine. Floor tiles can also be made from xylolite. MOC is also used in the construction industry as a wood wool binder in shavings-magnesia plates. With inert fillers and coloring pigment, Sorel cement may also be used to manufacture factitious stone and artificial ivory, as in the case of billiard balls. MOC is also used as a mastic for joining glass and metal, and as a binder for grinding $[1,2]$. On the other hand, it must be aware the poor water resistance of Sorel cement which can be improved by some additives $[4,5]$. 
Traditional fillers introduced into MOC paste are, for example, sawdust, ground quartz sand, talc, saponite or marble powder. In the last several years, studies on modified Sorel cements containing fly ash or granite wastes as fillers have also been conducted [6]. Authors used crushed granite (from the residues of cut granite blocks) and dried granite sludge (from granite polishing). In these studies the authors also used a constant additive of fly ash (20 mass \%) in order to improve the workability and resistance to moisture of the hardened material.

Others described the use of Sorel cement to stabilise fly ash which was created in municipal waste incinerators and to immobilise heavy metals from this ash [7]. An increase in the compressive strength of MOC with fly ash was found. Moreover, a leaching study of heavy metals from fly ash and bound in a Sorel cement matrix was carried out. It was found that in ash the content of heavy metals exceeded the limit, while in samples bound by MOC, concentrations of these elements were below the limit values by appropriate standards.

Another example of the unconventional use of Sorel cement is solidification and stabilisation of sludge from wastewater [8]. The authors state that the use of Sorel cement increased solidification of the wastewater sludge. In consequence, the leaching test of some metals from the solidified product showed that along with an increase in the share of Sorel cement in the materials, the effectiveness of the retention of heavy metals also increased.

Study on the removal of synthetic dyes from the wastewater of textile factories by using Sorel cement was also conducted [9]. It was found that the amount of adsorbed dye increased with prolonged contact time of the adsorbent, the amount of dose as well as with increasing temperature. The authors compared the adsorption capacity of magnesia cement to other natural and artificial adsorbents (e.g. zeolites, calcined alunite) used for the removal of dyes from the wastewater, and it was found that Sorel cement is a particularly effective adsorbent.

Asbestos wastes could be also treated as potential Sorel cement fillers. Asbestos is a commercial name for silicate minerals that have a fibrous structure. Asbestos minerals are divided into two groups depending on their crystal structure: serpentine and amphibole. The former group includes chrysotile $\left(\mathrm{Mg}_{3}\left[\mathrm{Si}_{2} \mathrm{O}_{5}\right](\mathrm{OH})_{4}\right)$, while the amphibole group comprises five minerals: actinolite $\left(\mathrm{Ca}_{2}(\mathrm{Mg}, \mathrm{Fe})_{5}\left[(\mathrm{OH}) \mathrm{Si}_{4} \mathrm{O}_{11}\right]_{2}\right)$, amosite $\left((\mathrm{Fe}, \mathrm{Mg})_{7}[(\mathrm{OH})\right.$ $\left.\left.\mathrm{Si}_{4} \mathrm{O}_{11}\right]_{2}\right)$, anthophyllite $\left((\mathrm{Mg}, \mathrm{Fe})_{7}\left[(\mathrm{OH}) \mathrm{Si}_{4} \mathrm{O}_{11}\right]_{2}\right)$, crocidolite $\left(\mathrm{Na}_{2} \mathrm{Fe}_{3} \mathrm{Fe}_{2}\left[(\mathrm{OH}) \mathrm{Si}_{4} \mathrm{O}_{11}\right]_{2}\right)$ and tremolite $\left(\mathrm{Ca}_{2} \mathrm{Mg}_{5}\right.$ $\left.\left[(\mathrm{OH}) \mathrm{Si}_{4} \mathrm{O}_{11}\right]_{2}\right)$ [10-12].

On an industrial scale only three asbestos minerals were widely used: chrysotile (white asbestos), crocidolite (blue asbestos) and amosite (brown asbestos). At the time of its greatest popularity, asbestos was used in the production of about 3000 different products. It was one of the most popular and cheapest raw materials used in the building materials industry. The largest quantities of mined asbestos were used for the manufacturing of cement-asbestos products which were made only from two raw materials (Portland cement and asbestos) and water [13-16].

On the other hand, it is unquestionable that asbestos has carcinogenic properties. It has been shown that the fibrous structure of asbestos has crucial importance in its biological activity, so the linear dimensions of asbestos fibres are an important factor which should be considered as a dangerous one $[17,18]$. In the human environment there are still many such materials which pose a huge ecological problem due to the proved carcinogenic effect of asbestos. According to the "Programme of removing asbestos and asbestos-containing products used on the territory of Poland", which was adopted by the Polish Government, all asbestos-containing products will have been removed by the year 2032. The only method of asbestos waste neutralisation that is currently applied in Poland remains its storage in special landfills for hazardous waste, which does not solve the problem in the long term. This method of asbestos waste neutralisation appears to be only a partial solution as it does not completely destroy the fibrous structure of asbestos but only isolates it from the environment.

It therefore seems appropriate to develop methods for the neutralisation and utilisation of asbestos and asbestos products mainly through destruction of the fibrous structure so that the resulting non-toxic material can be used in practical applications. One such method is thermal treatment. This process leads to thermal decomposition of asbestos which is associated with the loss of chemically bound water from the asbestos structure. This leads to a change in the crystalline structure and the formation of new phases that do not have dangerous properties [19-24]. Such obtained material may have huge application potential and could be successfully used in recycling technologies. One of these could be for it to be utilised as a filler in magnesium oxychloride cement (MOC).

The aim of the present study was to perform studies on the use of asbestos wastes (previously calcined chrysotile asbestos and cement-asbestos roofing slate) as potentially possible Sorel cement fillers. Preliminary assessment of the suitability of asbestos wastes as fillers was based on technical parameters, such as setting time and compressive strength. Mineral composition and related material microstructures were also investigated.

\section{EXPERIMENTAL}

\section{Characteristics of the used raw materials}

The basic raw materials used in this study were reactive magnesium oxide obtained by calcination of natural magnesite (Grochów, Poland) at a temperature of $700^{\circ} \mathrm{C}$ and a water solution of magnesium chloride at 
a concentration of 25 mass \% prepared from the commercial reagent $\mathrm{MgCl}_{2} \cdot 6 \mathrm{H}_{2} \mathrm{O}$ (Chempur). The following were used as fillers:

- chrysotile asbestos calcined at $700^{\circ} \mathrm{C}$ and subsequently ground; the asbestos used here came from a supply (Russia) for the "Zachem" plants in Bydgoszcz (Poland). It was applied there for the preparation of diaphragms used in electrochemical processes;

- corrugated cement-asbestos slate calcined at $700^{\circ} \mathrm{C}$ and subsequently ground; it had been removed from a farm building in Upper Silesia, in the vicinity of the town of Mikołów; it had been exposed to outside weather conditions for about 30 years; both yellowishgreen and dark-blue bundles of fibres were observed in the fracture of the sample.

Various instrumental techniques, such as differential thermal analysis (DTA), thermogravimetric analysis (TGA), X-ray diffraction (XRD) and scanning electron microscopy (SEM), infrared spectroscopy (FT-IR) were applied in order to characterise the raw materials used here. The size distribution of solid materials was also determined using sieve analysis. The thermal analysis was performed using a thermal analyser Paulik-PaulikErdey system (MOM company, Hungary) in a temperature range of $20-1000^{\circ} \mathrm{C}$. The measurement was conducted in an alumina crucible using $\mathrm{Al}_{2} \mathrm{O}_{3}$ as a reference. The heating rate was $10 \mathrm{~K} \cdot \mathrm{min}^{-1}$. XRD analysis of the examined samples was carried out using a Seifert XRD 3003 TT diffractometer $\left(\mathrm{CuK}_{\alpha}\right.$ radiation, Ni filter, $40 \mathrm{kV}, 30 \mathrm{~mA}$ ). IR-spectra were measured on a Nicolett 6700 FT-IR spectrophotometer (ATR method). The microstructure was examined by a scanning electron microscope (Hitachi TM-3000).

Figure 1 shows the thermal analysis curves of "Grochów" natural and calcined magnesite. Endothermic effects on DTA connected with the mass loss in the TG curve for the natural variety are due to the decomposition of the carbonates $\mathrm{MgCO}_{3}\left(\mathrm{~T}_{\max }=660^{\circ} \mathrm{C}\right)$ and $\mathrm{CaCO}_{3}$ $\left(\mathrm{T}_{\max }=810^{\circ} \mathrm{C}\right)$. The latter occurs in the raw material as an admixture derived from the magnesite deposit.

In order to obtain reactive $\mathrm{MgO}$ from the magnesite, it was calcined at $700^{\circ} \mathrm{C}$ for $2 \mathrm{~h}$ in a laboratory silite furnace. Then the degree of $\mathrm{MgCO}_{3}$ degradation was checked by performing thermal analysis. Due to the incomplete decomposition of magnesium carbonate, additional 2-hour calcination of the raw material at a temperature of $700^{\circ} \mathrm{C}$ was performed. Next, the resulting product was milled for $15 \mathrm{~min}$ in a ball mill and then subjected to thermal analysis (Figure 1), which confirmed complete decomposition of $\mathrm{MgCO}_{3}$. On the DTA curve only one weak endothermic effect associated with mass loss was observed. This effect indicates thermal decomposition of calcite, which was only partially decomposed during the calcination of raw materials in the furnace at $700^{\circ} \mathrm{C}$. The X-ray diffraction patterns of the product obtained by calcining magnesite at $700^{\circ} \mathrm{C}$ for $4 \mathrm{~h}(\mathrm{Fi}-$ gure $2 \mathrm{a}$ ) clearly show the presence of magnesium oxide.

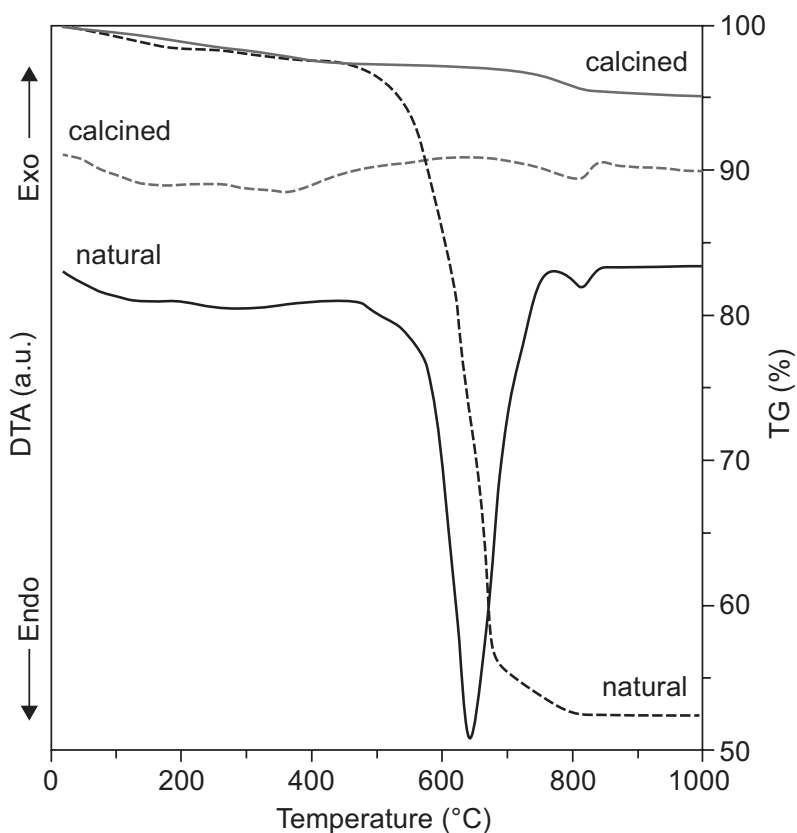

Figure 1. DTA and TG curves of natural magnesite „Grochów” and after calcintation at $700^{\circ} \mathrm{C} / 4 \mathrm{~h}$.

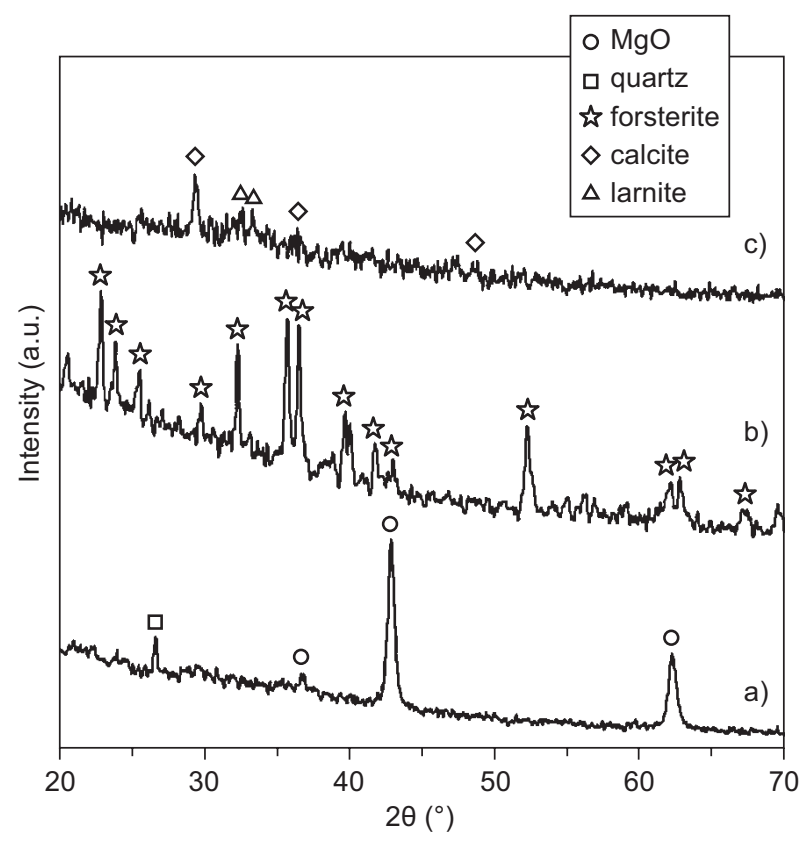

Figure 2. XRD patterns of calcined „Grochów” magnesite (a), calcined chrysotile asbestos (b), calcined cement-asbestos (c).

Detailed characteristics of the asbestos wastes used in this study were previously described [25-27]. In the case of the asbestos sample, chrysotile $\left(\mathrm{Mg}_{3}\left[\mathrm{Si}_{2} \mathrm{O}_{5}\right]\right.$ $(\mathrm{OH})_{4}$; as a main component) as well as admixtures of brucite $\mathrm{Mg}(\mathrm{OH})_{2}$ and portlandite $\mathrm{Ca}(\mathrm{OH})_{2}$ were detected. By using thermal analysis methods it was found that chrysotile lost chemically bound water in a temperature range from 600 to $800^{\circ} \mathrm{C}$, and the resulting amorphous dehydroxylation material crystallised into forsterite $\left(\mathrm{Mg}_{2} \mathrm{SiO}_{4}\right)$ [25]. 
According to study [27] under dynamic heating the maximum rate for the dehydroxylation process of chrysotile samples from different regions was recorded in a temperature range of $700-730^{\circ} \mathrm{C}$. Based on the abovementioned studies, a heat treatment temperature was selected for the chrysotile asbestos used in the studies. The asbestos sample was placed in alumina crucibles and calcined at $700^{\circ} \mathrm{C}$ for $2 \mathrm{~h}$, then, after cooling, it was ground for $5 \mathrm{~min}$ in a vibratory mill to give a fine powder. Phase composition of powder obtained by the XRD method confirmed complete chrysotile thermal decomposition and clearly showed only the presence of forsterite (Figure $2 b$ ).

The cement-asbestos slate used in the study contained white and blue asbestos fibres, i.e. chrysotile and crocidolite, respectively. The main crystalline phases identified in cement-asbestos were portlandite $\mathrm{Ca}(\mathrm{OH})_{2}$ and calcite $\mathrm{CaCO}_{3}$. Dicalcium silicate (belite) $\mathrm{Ca}_{2} \mathrm{SiO}_{4}$ and a small amount of ettringite $3 \mathrm{CaO} \cdot \mathrm{Al}_{2} \mathrm{O}_{3} \cdot 3 \mathrm{CaSO}_{4} \cdot 32 \mathrm{H}_{2} \mathrm{O}$ were also identified [24]. The material was calcined at $700^{\circ} \mathrm{C}$ for $2 \mathrm{~h}$, then ground in a ball mill for $4 \mathrm{~h}$. The calcination temperature was chosen to ensure thermal decomposition (dehydroxylation process) of the asbestos minerals $[27,28]$ contained in the cement-asbestos and, on the other hand, to limit the thermal decomposition of calcite, which occurs at a temperature range of 800 to $900^{\circ} \mathrm{C}$. To confirm the thermal decomposition of asbestos minerals included in the cement-asbestos material, material obtained after calcination was studied by the FT-IR method and compared with the IR spectrum of raw cement-asbestos (Figure 3). Absorbance bands related to the stretch of $\mathrm{OH}$ groups from asbestos minerals are visible on the FT-IR spectrum of the raw cementasbestos sample in the high wavenumber region while after calcination at $700^{\circ} \mathrm{C}$ the disappearance of they

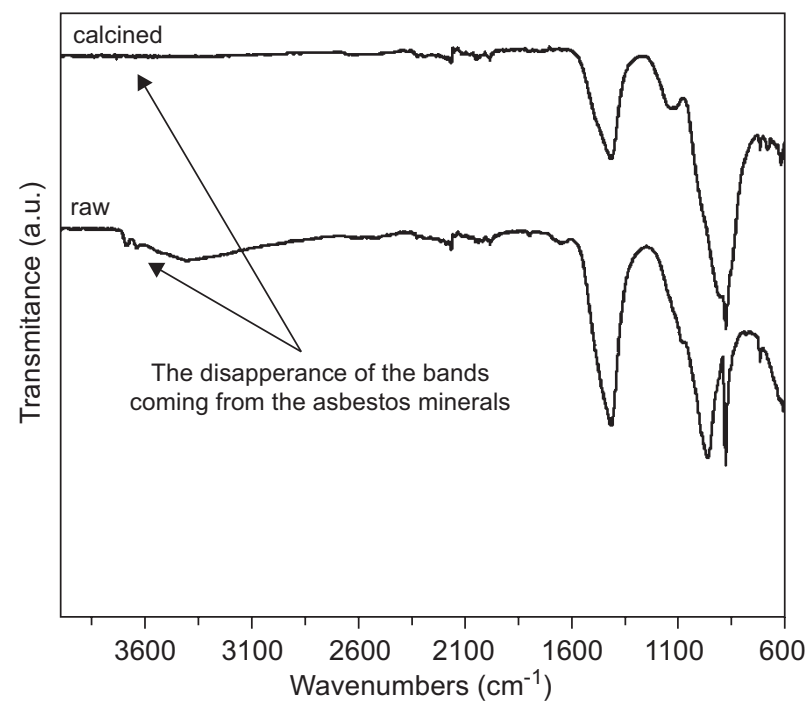

Figure 3. FT-IR spectra of raw cement-asbestos sample and after thermal treatment at $700^{\circ} \mathrm{C} / 2 \mathrm{~h}$. occur. Mainly calcite and dicalcium silicate (the mineralogical name larnite; the cement notation: belite) were identified using the XRD method in the obtained product (Figure 2c).

In order to confirm the destruction of the hazardous fibrous structure for both of the asbestos wastes used, SEM observation of chrysotile asbestos and cementasbestos (raw and after heat treatment) was also conducted (Figures 4 and 5). The characteristic fibrous structure of asbestos was observed in both waste samples before heat treatment; whereas after calcination at $700^{\circ} \mathrm{C}$ the fibres became extremely fragile and were easily broken. Short-time milling of the obtained product allowed to obtain fine powders used as Sorel cement fillers in the next stage of the investigation. The grain size of the obtained asbestos-free raw materials used in the further step is given in Table 1.

\section{Sorel cement samples preparation and their test methods}

Samples composed of reactive magnesium oxide and calcined chrysotile asbestos or cement-asbestos, respectively, were prepared. The amount of the asbestos wastes was 0,20 , or 40 mass $\%$. After adding $\mathrm{MgCl}_{2}$ solution to the raw materials mass, the setting time was measured using the Vicat method. The compressive strength of the obtained magnesium oxychloride cement (MOC) samples after 3, 7 and 28 days of hardening was also tested. Samples for strength test were prepared by placing the Sorel cement paste in the ring forms with a diameter of $30 \mathrm{~mm}$ and high $20 \mathrm{~mm}$. Then, after hardening of samples, they were pulled from the form and kept for desired time (3, 7 or 28 days) in air-dry conditions. The remaining material obtained after the compressive strength test for samples after 28 days of hardening was used to study the phase composition (XRD), thermal properties by differential thermal analysis (DTA) as well as microstructure (SEM).

Table 1. Sieve analysis of used raw materials.

\begin{tabular}{cccc}
\hline \multirow{2}{*}{$\begin{array}{c}\text { Grain class } \\
(\mathrm{mm})\end{array}$} & $\begin{array}{c}\text { Calcined } \\
\text { "Grochów" } \\
\text { magnesite }\end{array}$ & $\begin{array}{c}\text { Calcined } \\
\text { chrysotile } \\
\text { asbestos }\end{array}$ & $\begin{array}{c}\text { Calcined } \\
\text { cement- } \\
\text {-asbestos }\end{array}$ \\
\hline$>0.5$ & 6 & 0 & 0 \\
$0.5-0.25$ & 36 & 83 & 50 \\
$0.25-0.20$ & 40 & 7 & 32 \\
$0.20-0.15$ & 10 & 0 & 10 \\
$0.15-0.12$ & 4 & 3 & 4 \\
$0.12-0.10$ & 4 & 7 & 4 \\
$<0.10$ & 0 & 0 & 0 \\
\hline
\end{tabular}




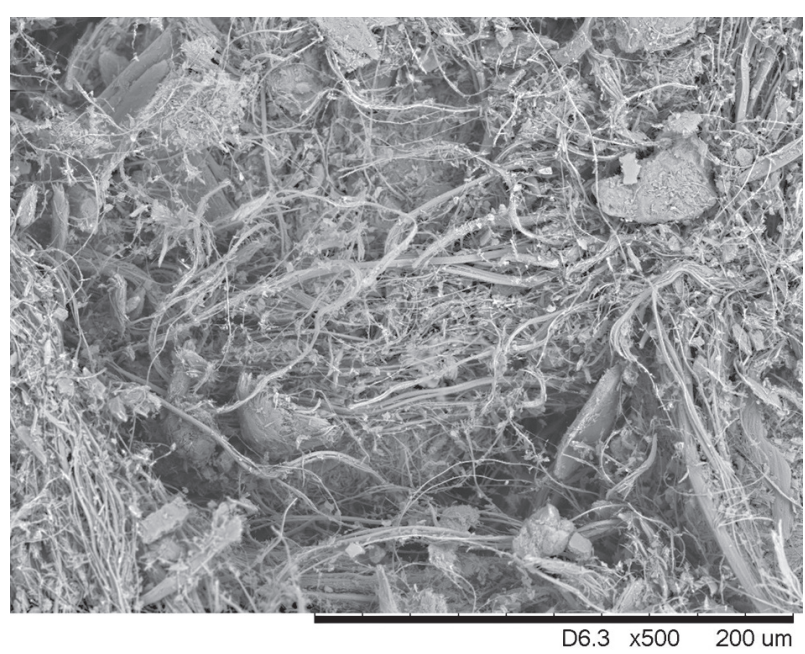

a)

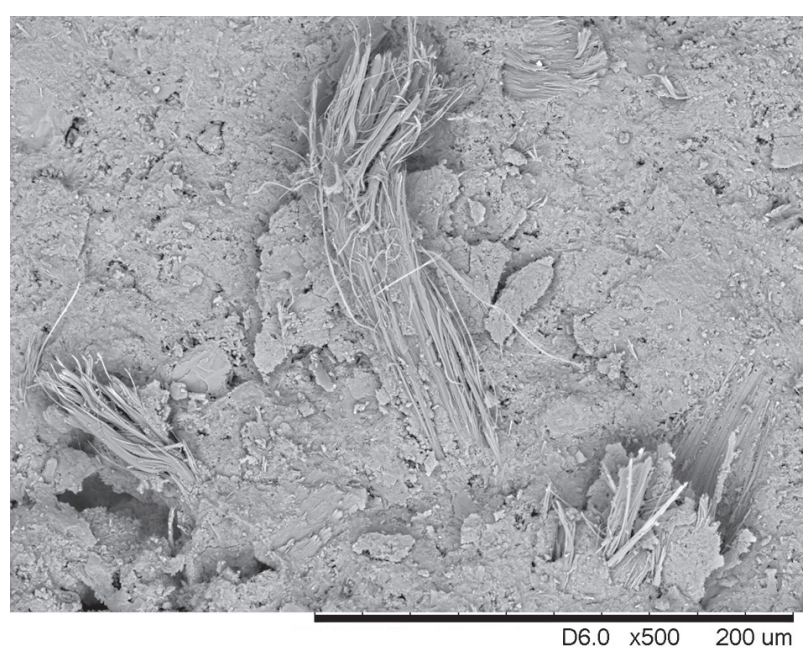

a)

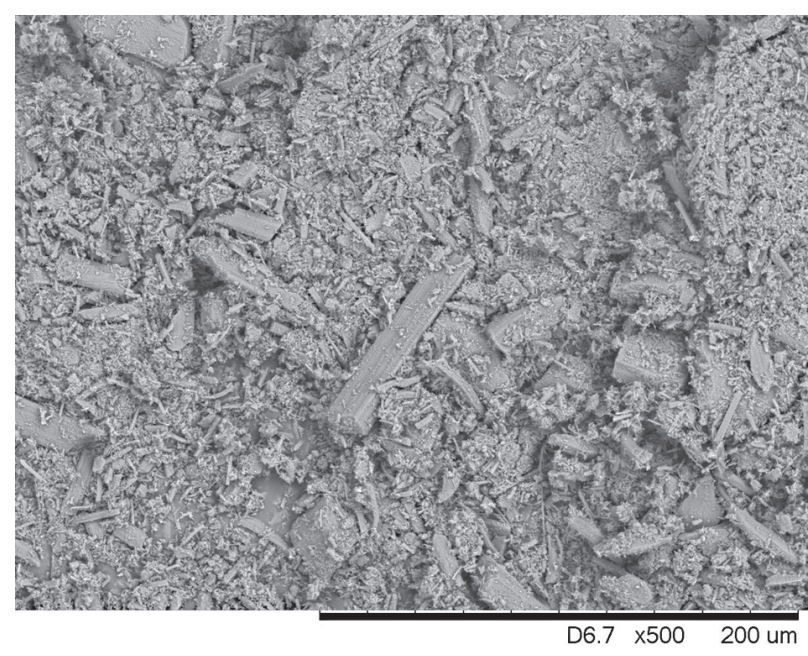

b)

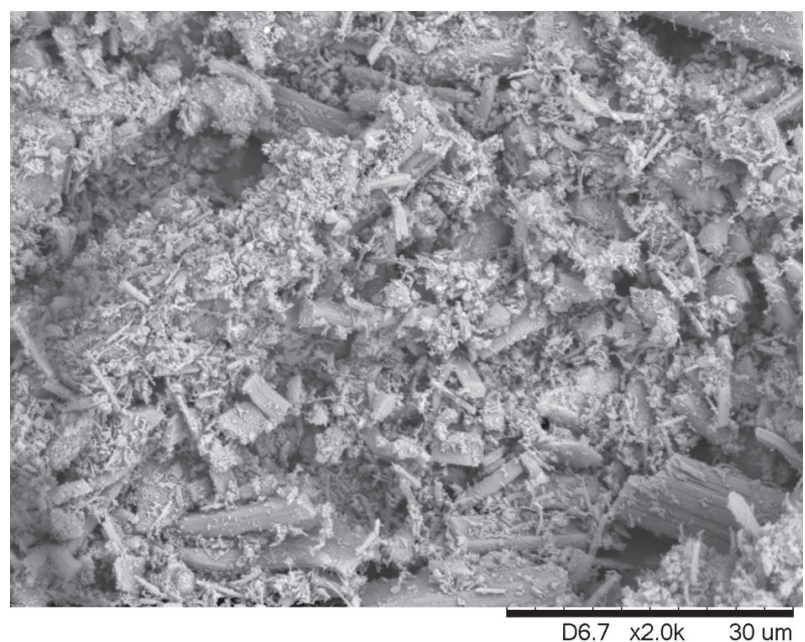

c)

Figure 4. SEM images of chrysotile asbestos: raw, $\times 500$ (a), calicned and ground, $\times 500(b), \times 2000(c)$.

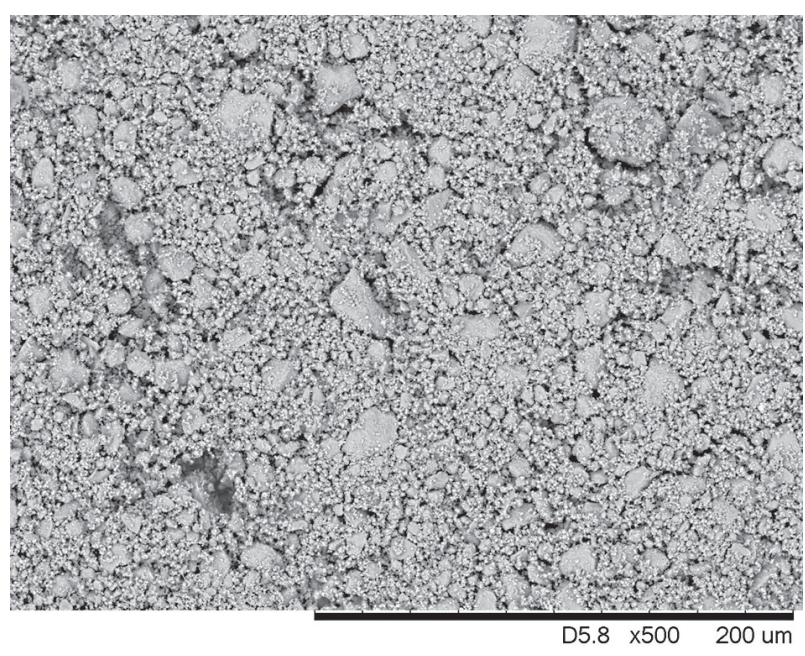

b)

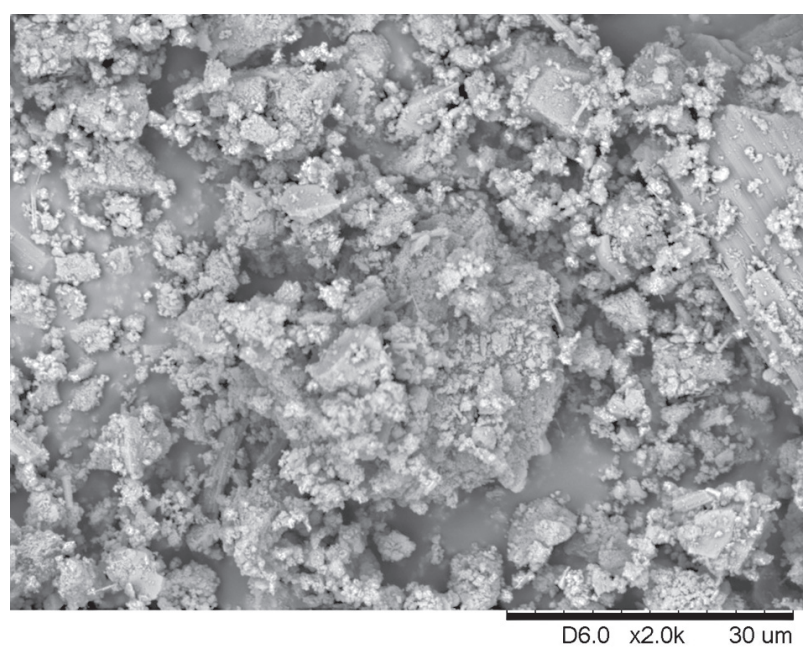

c)

Figure 5. SEM images of used cement-asbestos slate: raw, $\times 500$ (a), calcined and ground, $\times 500$ (b), $\times 2000$ (c). 


\section{RESULTS AND DISCUSSION}

The test results of the setting time and compressive strength at 3, 7 and 28 days of hardening are given in Table 2. The X-ray patterns of obtained Sorel cements are shown in Figure 6. Figure 7 shows an exemplary fracture microstructure of the obtained Sorel cement samples containing asbestos wastes as fillers and the Sorel cement sample without such an additive, after 28 days of hardening. In turn, DTA curves of materials obtained after 28 days of hardening are presented on Figure 8.

Sorel cement is characterised by a short setting time. Partial replacement of reactive magnesium oxide by calcined asbestos wastes contributed to a shift in the time and, consequently, the beginning and end of the setting time of the samples occurred later as compared to the MOC sample without any filler. However, the setting times of the MOC samples with fillers did not differ significantly from the MOC setting time without the addition of asbestos wastes (Table 2). Only in the

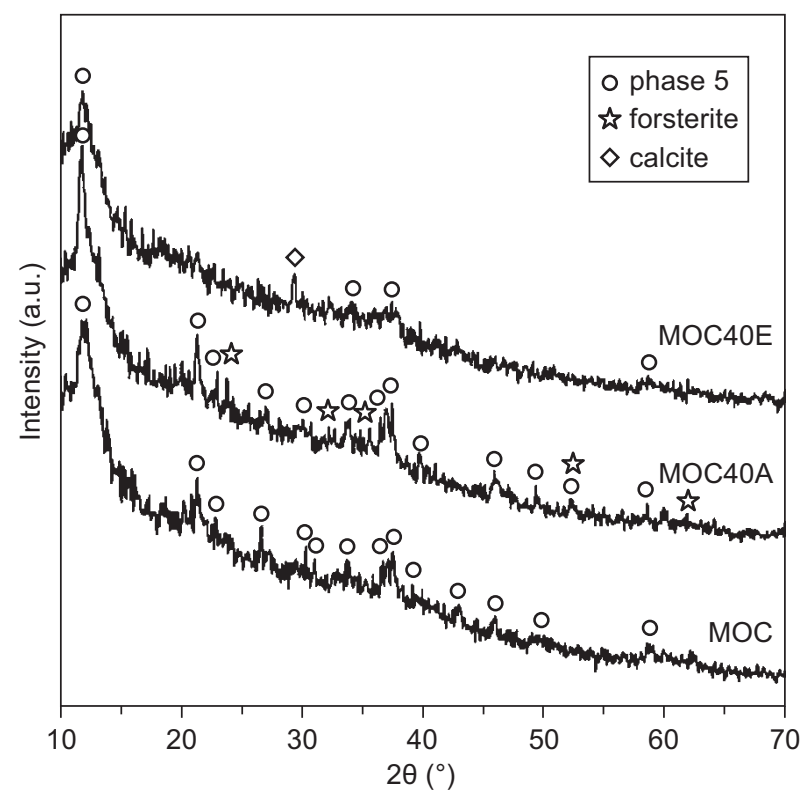

Figure 6. XRD patterns of obtained Sorel cement sample. case of a significant amount of calcined cement-asbestos (40 mass \% in the raw materials composition) did the bonding and hardening process run faster, and it was different in comparison to the samples containing 40 mass \% of calcined chrysotile asbestos. However, it should be noted that the phase composition of the asbestos wastes used here was significantly different (Figure 2). For previously calcined chrysotile asbestos, forsterite $\left(\mathrm{Mg}_{2} \mathrm{SiO}_{4}\right)$ was the dominant crystalline phase, while for the calcined cement-asbestos sample these were calcite $\mathrm{CaCO}_{3}$ and larnite (dicalcium silicate, $\mathrm{Ca}_{2} \mathrm{SiO}_{4}$ ). The phase composition of previously calcined cement-asbestos is much more complicated than it is in Figure 2c. On the X-ray diffraction pattern no clear peaks are visible of the dehydroxylation products of asbestos minerals or of calcium oxide (from the thermal decomposition of portlandite or the onset, at $700^{\circ} \mathrm{C}$, of the decomposition of calcium carbonate). This phenomenon can be explained as follows: due to the small number of these phases and only an initiated thermal decomposition process of calcite, the above-mentioned potential compounds were not detected (which was also related to the diffraction limit of detection as well as to the disturbed crystal structure).

The Sorel cements tested in this study bound more slowly in comparison to building gypsum and bound faster when compared with Portland cement. The gypsum binder begins to bind after 3-6 min, and the end occurs after $30 \mathrm{~min}$. Portland cement begins the setting and hardening process no earlier than after 40-60 min, while the end of the process takes place no later than after 8 hours $[29,30]$.

A general trend observed for the MOC tested samples was that good compressive strength was achieved within a short period of time (three days' maturation). Prolonging this period to 7 and 28 days did not significantly increase the compressive strength, especially for the MOC samples with fillers (Table 2). The greatest value of compressive strength (above $40 \mathrm{MPa}$ ) was measurement of the MOC sample prepared from a raw mix containing 20 mass $\%$ of calcined chrysotile asbestos. Increasing the share of this filler to 40 mass $\%$ of the samples resulted in a decrease in the compressive strength

Table 2. Setting time and compressive strength of obtained Sorel cement samples.

\begin{tabular}{|c|c|c|c|c|c|c|c|c|c|}
\hline \multirow[b]{2}{*}{ Set symbol } & \multicolumn{3}{|c|}{$\begin{array}{l}\text { Composition } \\
(\text { mass \%) }\end{array}$} & \multicolumn{3}{|c|}{$\begin{array}{c}\text { Setting time of obtained Sorel cement } \\
\text { samples (min) }\end{array}$} & \multicolumn{3}{|c|}{ Compressive strength $(\mathrm{MPa})$} \\
\hline & $\begin{array}{l}\text { Calcined } \\
\text { „Grochów" } \\
\text { magnesite }\end{array}$ & $\begin{array}{c}\text { Calcined } \\
\text { chrysotile } \\
\text { asbestos }\end{array}$ & $\begin{array}{l}\text { Calcined } \\
\text { cement- } \\
\text { asbestos }\end{array}$ & Beginning & End & $\begin{array}{l}\text { Setting } \\
\text { time }\end{array}$ & 3 days & 7 days & $\begin{array}{c}28 \\
\text { days }\end{array}$ \\
\hline $\mathrm{MOC}$ & 100 & - & - & 23 & 41 & 18 & 30 & 38 & 39 \\
\hline MOC20A & 80 & 20 & - & 48 & 67 & 19 & 43 & 46 & 46 \\
\hline MOC40A & 60 & 40 & - & 67 & 89 & 22 & 24 & 25 & 28 \\
\hline MOC20E & 80 & - & 20 & 40 & 64 & 24 & 34 & 32 & 34 \\
\hline MOC40E & 60 & - & 40 & 25 & 39 & 14 & 11 & 14 & 18 \\
\hline
\end{tabular}




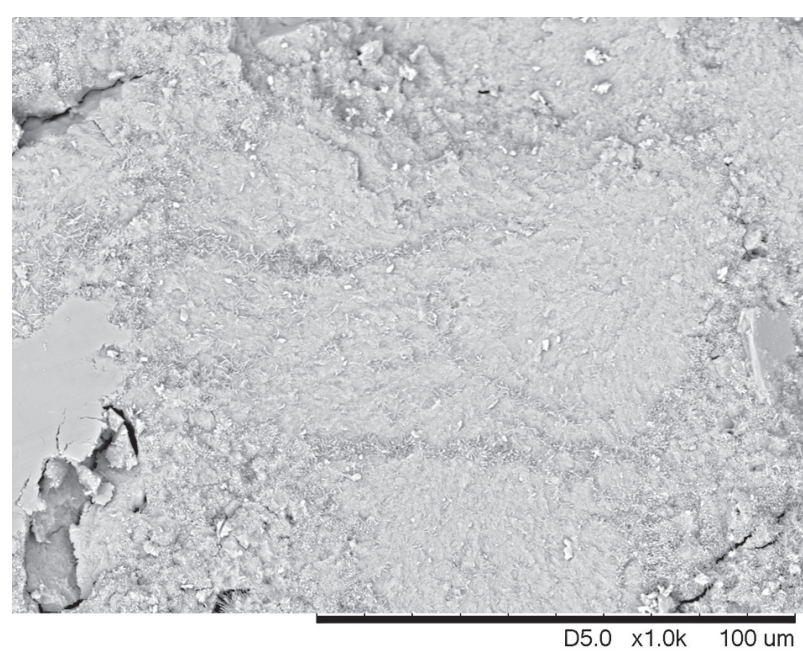

a)

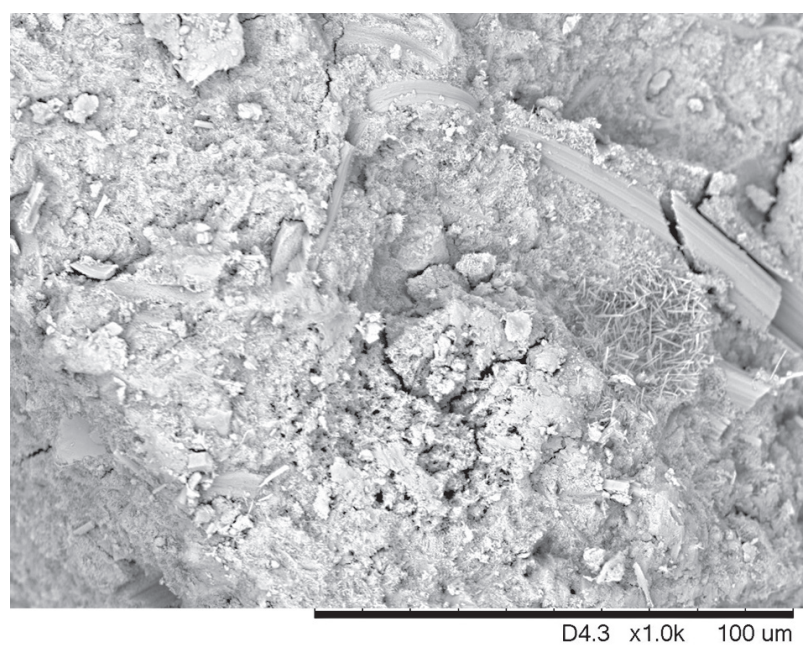

c)

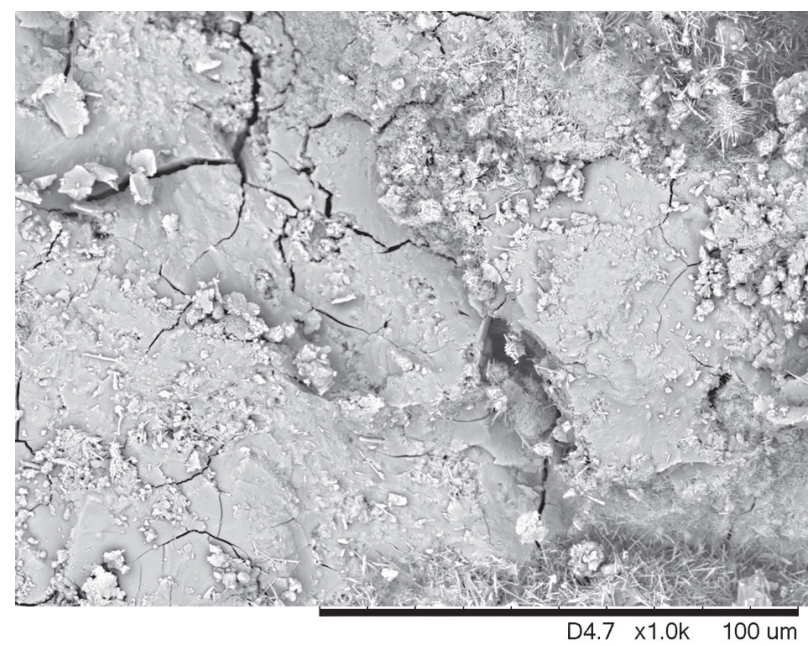

e)

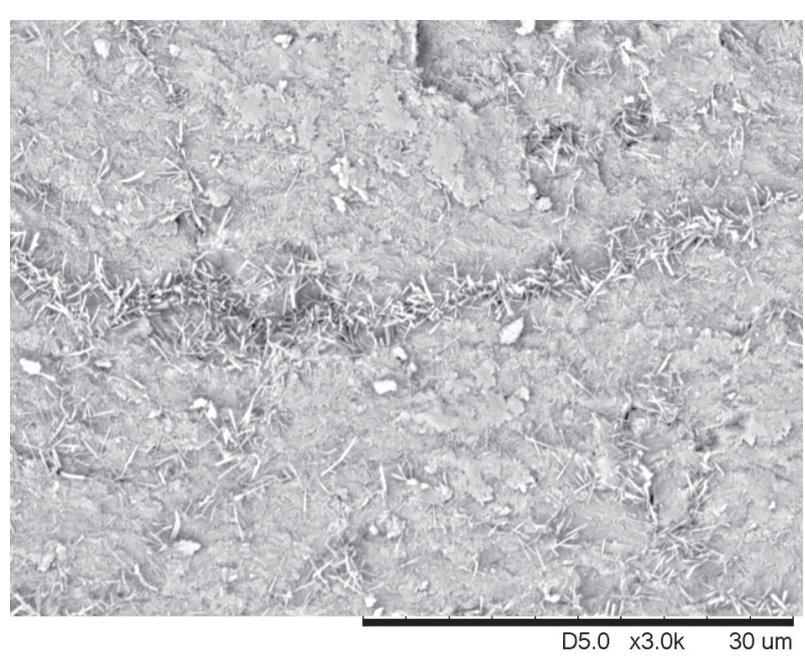

b)

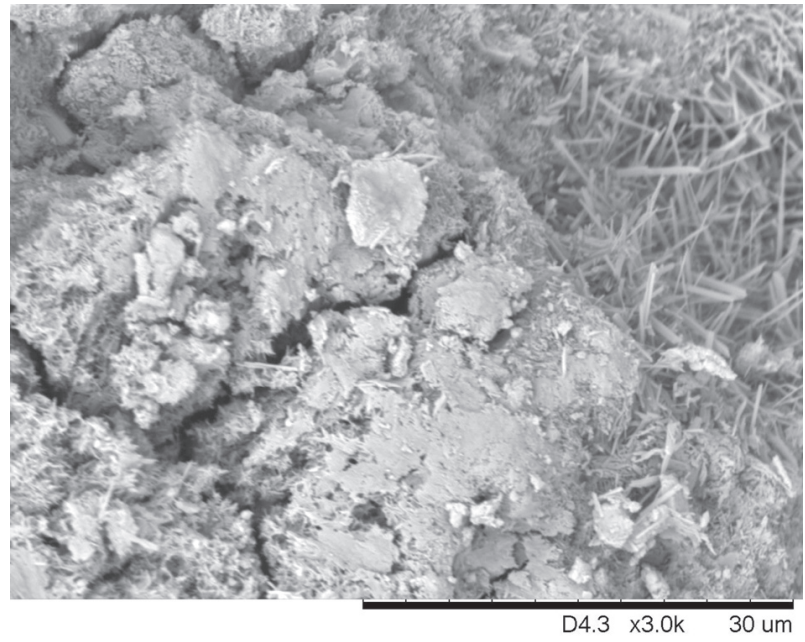

d)

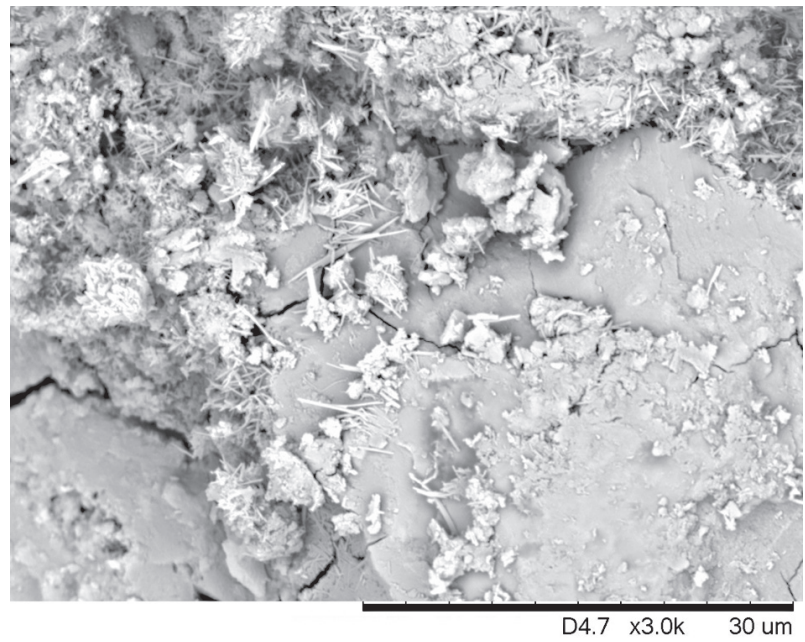

f)

Figure 7. Fracture SEM images of obtained Sorel cement samples after 28 days of setting and hardening: without addition of asbestos wastes $(a, b)$; with 40 mass $\%$ of calcined asbestos (c, d); with 40 mass $\%$ of calcined cement-asbestos (e, f). Different magnification: $\times 1000(a, c, e) ; \times 3000(b, d, f)$. 
of the MOC sample. This is particularly evident in the case of the MOC sample with calcined cement-asbestos. This may be due to the presence of calcium chloride. The most harmful dopant in the magnesia raw materials used in the preparation of magnesium oxychloride cement is calcium oxide, which may form harmful $\mathrm{CaCl}_{2}$ that may contribute to reducing the strength and increasing the hygroscopicity of the MOC [2]. The presence of calcium oxide in the cement-asbestos used here may be due to the decomposition of $\mathrm{CaCO}_{3}$, which started during the thermal pre-treatment of asbestos wastes at $700^{\circ} \mathrm{C}$. In addition, phase composition of the MOC samples after 28 days of setting and hardening showed that Phase 5, which determines the strength, occurred the least in the sample with cement-asbestos as compared to unfilled Sorel cement and MOC with calcined chrysotile asbestos (Figure 6).

Microstructure observation of the hardened samples confirmed the presence of typical MOC phases (like Phase 5 or Phase 3), which formed the characteristic needle crystals (Figure 7). They were observed for each bonded Sorel cement materials and this it in accordance with other authors [31]. Although due to the large amount of fillers (40 mass \%) in the prepared samples, the presence of these microstructures is limited, especially for materials with calcined cement-asbestos fillers. SEM images of the MOC sample with calcined asbestos (Figure 7c) show a characteristic single strip of forsterite "embedded" in the MOC matrix which results from the thermal treatment and decomposition of chrysotile asbestos.

Due to the presence of asbestos fillers, DTA curves shape of obtained Sorel cement samples has also changed. This is particularly evident for material with pre-calcined cement-asbestos filler (Figure 8). It was stated that thermal decomposition of Phase 3 as well as Phase 5 of bounded Sorel cement material occurs at five endothermic steps in the temperature range $75-600^{\circ} \mathrm{C}$ [32]. Since the lowest temperature the gradually loss of crystallization water from Phases 3 and 5 occurs, followed by dehydroxylation process and breaks down a substance connection with release of hydrogen chloride. This process can be described as an overall reactions: $3 \mathrm{Mg}(\mathrm{OH})_{2} \cdot \mathrm{MgCl}_{2} \cdot 8 \mathrm{H}_{2} \mathrm{O} \rightarrow 4 \mathrm{MgO}+2 \mathrm{HCl}+10 \mathrm{H}_{2} \mathrm{O}$ (for Phase 3) or $5 \mathrm{Mg}(\mathrm{OH})_{2} \cdot \mathrm{MgCl}_{2} \cdot 8 \mathrm{H}_{2} \mathrm{O} \rightarrow 6 \mathrm{MgO}+2 \mathrm{HCl}$ $+12 \mathrm{H}_{2} \mathrm{O}$ (for Phase 5). These five stages are presented on DTA curve for MOC sample (without any fillers). There are two endothermic peaks at 200 and $360^{\circ} \mathrm{C}$ as well as three clearly visible inflection points at 260, 420 and $500^{\circ} \mathrm{C}$. These five similar effects can be traced for MOC40A sample, however their intensity is lower caused by "dilution" of the sample by 40 mass \% of thermally inert filler like pre-calcined chrysotile asbestos. The other nature of the DTA curve was observed for the obtained Sorel cement material based on pre-calcined cementasbestos as filler (MOC40E). Instead of five endothermic effects typical for Sorel cement phases, in the temperature range $75-600^{\circ} \mathrm{C}$ only two broad effects were observed. The largest difference can be seen at temperature about $400^{\circ} \mathrm{C}$, where only one effect is visible. This effect probably comes from the alignment of the effects derived from thermal decomposition of magnesium oxychloride cement phases and calcium hydroxide. The latter is a secondary product and formed by the hydration of free calcium oxide (from pre-calcined cementitious matrix of cement-asbestos waste) in the presence of an aqueous solution of magnesium chloride. $\mathrm{Ca}(\mathrm{OH})_{2}$ it is also one of the main products formed beside CSH phase during setting of cement binder. Unreacted clinker phase such as belite $\left(\mathrm{C}_{2} \mathrm{~S}\right.$ in cementitious notation) was identified in considered cement-asbestos material used for research. At temperature about $700^{\circ} \mathrm{C}$ inconsiderable endothermic effect form decomposition of calcite was also observed.

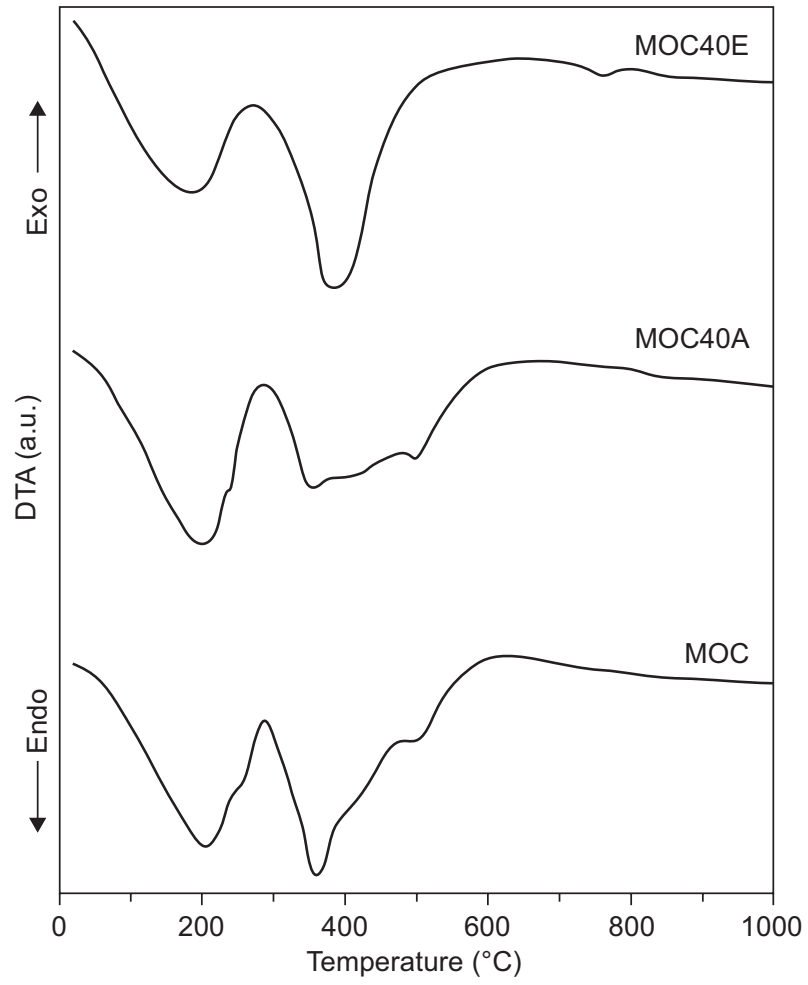

Figure 8. DTA curves comparison of obtained Sorel cement samples without any fillers (MOC) and with 40 mass \% of calcined chrysotile asbestos (MOC40A) or calcined cementasbestos (MOC40E).

\section{CONCLUSION}

The results obtained here indicate that materials containing asbestos can be used as Sorel cement (magnesium oxychloride cement, MOC) fillers. However, thermal pre-treatment is necessary in order to destroy the fibrous, carcinogenic structure of asbestos minerals, such as chrysotile and crocidolite, in the case of this study. Use of these fillers delayed the onset of the 
setting and hardening process, but the setting time was comparable to that of unmodified Sorel cement. The compressive strength of the MOC with 20 mass \% of calcined chrysotile asbestos exceeded the strength of the reference MOC sample (without any addition of filler) for all applicable times of ripening, i.e. 3, 7 and 28 days, and reached a value above $40 \mathrm{MPa}$. Less favourable results were obtained using calcined cementasbestos as a filler due to its more complicated mineral composition. The results presented here may be an initial step for further research focusing on the use of MOC with calcined asbestos wastes for immobilisation of heavy metals from fly ash and sewage sludge.

\section{Acknowledgments}

The authors wish to thank Mrs. M. Dtugi for help in manufacturing the samples. This work was partially supported by the statutory activity of the Institute of Ceramics and Building Materials and Silesian University of Technology.

\section{REFERENCES}

1. Bensted J. (2006): Sorel and related cements. Part 1: Sorel cement, also known as magnesium oxychloride cement (MOC). Cement-Wapno-Beton/Cement-Lime-Concrete, 5, 297-316. yadda identifier: bwmeta1.element.baztecharticle-BTB2-0030-0078

2. Qiao H., Cheng Q., Jinlei W., Yingying S. (2014): The application review of magnesium oxychloride cement. Journal of Chemical and Pharmaceutical Research, 6, 180-185.

3. Liu B., Thomas P.S., Ray A.S., Guerbois J.P. (2007): A TG analysis of the effect of calcination conditions on the properties of reactive magnesia. Journal of Thermal Analysis and Calorimetry, 88, 145-149. doi:10.1007/s10973-0068106-0

4. Li C., Yu H. (2010): Influence of fly ash and silica fume on water-resistant property of magnesium oxychloride cement. Journal of Wuhan University of Technology - Materials Science Edition, 25, 721-724. doi:10.1007/s11595-0100079-y

5. Malinowski S., Jaroszyńska-Wolińska J. (2015): The physical and mechanical properties of magnesium oxychloride cement-based materials. Budownictwo i Architektura, 14, 89-98. yadda identifier: bwmeta1.element.baztechec3462e7-f029-4eb4-a731-8cb98f824914

6. Li Y., Yu H., Zheng L., Wen J., Wu C., Tan Y. (2013): Compressive strength of fly ash magnesium oxychloride cement containing granite waste. Construction and Building Materials, 38, 1-7. doi:10.1016/j.conbuildmat.2012.06.016

7. Mačakowa S., Šiška F., Pliešovská N., Hepworth M. (1996): Solidification of fly ash from municipal solid waste incinerator by the use of Sorel cement. Acta Montanistica Slovaca, 1, 35-42.

8. Jianli M., Youcai Z., Jinmei W., Li W. (2010): Effect of magnesium oxychloride cement on stabilization/solidification of sewage sludge. Construction and Building Materials, 24, 79-83. doi:10.1016/j.conbuildmat.2009.08.011
9. Hassan S.S.M., Awwad N.S., Aboterika A.H.A. (2009): Removal of synthetic reactive dyes from textile wastewater by Sorel's cement. Journal of Hazardous Materials, 162, 994-999. doi:10.1016/j.jhazmat.2008.05.138

10. Szeszenia-Dąbrowska N. (2004). Asbestos. Occupational and environmental exposure. The effects and prevention. Instytut Medycyny Pracy, Łódź (in Polish)

11. Łuniewski A., Łuniewski S. (2007). Asbestos. The historical burden of the twentieth century. Wydawnictwo Ekonomia i Środowisko, Białystok (in Polish)

12. Leonelli C., Veronesi P., Boccaccini D.N., Rivasi M.R., Barbieri L., Andreola F., Lancellotti I., Rabitti D., Pellacani G.C. (2006): Microwave thermal inertisation of asbestos containing waste and its recycling in traditional ceramics. Journal of Hazardous Materials, 135, 149-155. doi:10.1016/j.jhazmat.2005.11.035

13. Buczek T., Dukowicz A. (2004): Directions in the utilization of asbestos and asbestos-cement products. Chemik, 12, 497-500. (in Polish) yadda identifier: bwmeta1.element. baztech-article-BPP1-0042-0064

14. Harris L.V., Kahwa I.A. (2003): Asbestos - old foe in $21^{\text {st }}$ century developing countries. Science of the Total Environment, 307, 1-9. doi:10.1016/S0048-9697(02)00504-1

15. Pyssa J., Rokita G.M. (2007): The asbestos - occurence, using and the way of dealing with asbestic waste material. Gospodarka Surowcami Mineralnymi/Mineral Resources Management, 23, 49-61. (in Polish) yadda identifier: bwmeta1.element.baztech-article-BPZ1-0042-0012

16. Virta R.L. (2005): Mineral commodity profiles - asbestos. U.S. Geological Survey circular 1255-KK

17. Więcek E. (2004): Asbestos - exposition and health effects. Bezpieczeństwo Pracy/Occupational Safety, 2, 2-6. (in Polish) yadda identifier: bwmeta1.element.baztech009e41a4-6f4d-4d7a-b4c3-c2185b9e9e00

18. Czekaj A., Dyczek J. (2002): Corrosion of asbestos-cement products and resulting asbestos emission hazard. Cement-Wapno-Beton/Cement-Lime-Concrete, 6, 270-275. (in Polish) yadda identifier: bwmeta1.element.baztecharticle-BTB2-0015-0162

19. Dellisanti F., Minguzzi V., Morandi N. (2001-2002): Experimental results from thermal treatment of asbestos containing materials. GeoActa, 1, 61-70.

20. Gualtieri A.F., Tartaglia A.: Thermal decomposition of asbestos and recycling in traditional ceramics. Journal of the European Ceramic Society, 20, 1409-1418. doi:10.1016/ S0955-2219(99)00290-3

21. Gualtieri A.F., Cavenati C., Zanatto I., Meloni M., Elmi G., Gualtieri M.L. (2008): The transformation sequence of cement-asbestos slates up to $1200^{\circ} \mathrm{C}$ and safe recycling of the reaction product in stoneware tile mixtures. Journal of Hazardous Materials, 152, 563-570. doi:10.1016/j.jhazmat. 2007.07.037

22. Hashimoto S., Takeda H., Okuda A., Kambayashi A., Honda S., Iwamoto Y., Fukuda K. (2008): Detoxification of industrial asbestos waste by low-temperature heating in a vacuum. Journal of the Ceramic Society of Japan, 116, 242-246. doi: 10.2109/jcersj2.116.242

23. Zaremba T., Peszko M. (2008): Investigation of the thermal modification of asbestos wastes for potential use in ceramic formulation. Journal of Thermal Analysis and Calorimetry, 92, 873-877. doi:10.1007/s10973-007-8111-y

24. Zaremba T., Krząkała A., Piotrowski J., Garczorz D. (2010): Utilization of chrysotile asbestos for sintering ceramics 
production. Materiaty Ceramiczne/Ceramic Materials, 62 , 149-155. (in Polish) yadda identifier: bwmeta1.element. baztech-article-AGH1-0023-0070

25. Zaremba T., Krząkała A., Piotrowski J., Garczorz D. (2010): Study on the thermal decomposition of chrysotile asbestos. Journal of Thermal Analysis and Calorimetry, 101, 479485. doi:10.1007/s10973-010-0819-4

26. Kusiorowski R., Zaremba T., Piotrowski J., Gerle A. (2013): Thermal decomposition of asbestos-containing materials. Journal of Thermal Analysis and Calorimetry, 113, 179188. doi:10.1007/s10973-013-3038-y

27. Kusiorowski R., Zaremba T., Piotrowski J., Adamek J. (2012): Thermal decomposition of different types of asbestos. Journal of Thermal Analysis and Calorimetry, 109, 693-704. doi:10.1007/s10973-012-2222-9

28. Kusiorowski R., Zaremba T., Gerle A., Piotrowski J., Simka W., Adamek J. (2015): Thermal decomposition of crocidolite asbestos. Journal of Thermal Analysis and
Calorimetry, 120, 1585-1595. doi:10.1007/s10973-0154421-7

29. Çolak A. (2000): Density and strength characteristics of foamed gypsum. Cement and Concrete Composites, 22, 193-200. doi:10.1016/S0958-9465(00)00008-1

30. Ylmèn R., Jäglid U., Steenari B.M., Panas I. (2009): Early hydration and setting of Portland cement monitored by IR, SEM and Vicat techniques. Cement and Concrete Research, 39, 433-439. doi:10.1016/j.cemconres.2009.01.017

31. Vandeperre L., Liska M., Al-Tabbaa A. (2008): Microstructures of reactive magnesia cement blends. Cement and Concrete Composites, 30, 706-714. doi:10.1016/j.cemconcomp. 2008.05.002

32. Xia S., Xing P., Gao S. (1991): Studies on the basic compounds of magnesia cement: the thermal behaviour of magnesium oxychlorides. Thermochimica Acta, 183, 349-363. doi:10.1016/0040-6031(91)80471-T 